
$\$$ Research Square
Preprints are preliminary reports that have not undergone peer review.
They should not be considered conclusive, used to inform clinical practice, or referenced by the media as validated information.

\title{
Solar Pumps and Water-Energy Nexus in Gujarat, India: First Assessment of the World's Largest Pilot on Grid-connected Solar Irrigation Pumps
}

\author{
Tushaar Shah ( $\nabla$ t.shah@cgiar.org ) \\ Institute of Rural Management, Anand https://orcid.org/0000-0002-0565-8464 \\ Gyan Rai \\ Independent researcher
}

\section{Article}

Keywords: solar irrigation pumps, farming, groundwater depletion, irrigation

Posted Date: July 14th, 2021

DOl: https://doi.org/10.21203/rs.3.rs-658617/v1

License: (c) (1) This work is licensed under a Creative Commons Attribution 4.0 International License.

Read Full License 


\section{Abstract}

The epicentre of Gujarat's perverse nexus between electricity subsidy and groundwater depletion lies in its legacy of 485,000 unmetered tubewell owners who have fiercely resisted metering for 20 years. These comprise 40 percent of Gujarat's irrigation connections but account for 49 percent of agricultural load, 71 percent of energy use in groundwater abstraction and 90 percent of farm power subsidies. Suryashakti Kisan Yojana (SKY), a large, state-wide pilot project which solarised and net-metered 4215 tubewells and began paying farmers for evacuating surplus solar energy, has been enthusiastically embraced by unmetered and metered farmers alike. SKY promises politically acceptable resolution of a wicked energywater conundrum that afflicts much of India and west Asia. Mainstreaming SKY can significantly reduce groundwater overdraft, GHG emissions and subsidy burden. It will increase farm incomes while radically improving energy-water accounting and management. Gujarat government should invest in compulsory, free-of-cost solarisation of tubewells. We show that doing so is profitable for government and beneficial for farmers, climate and environment.

\section{Main Text}

\section{Grid-connected Solar Pump Pilot in Gujarat}

In June 2018, Government of Gujarat (GoG) launched a US \$ 120 million[3] Suryashakti Kisan Yojana[4] (SKY) which planned to solarise some 12000 irrigation tubewells (140,000 Horse Power (HP) load) on 137 agricultural feeders in 33 districts of Gujarat. SKY was inspired by Dhundi village where the world's first solar farmers' cooperative has successfully operated since 2015 (Shah et al 2017; Shah et al 2018). Under SKY, solar pumps are net-metered but run on grid power while all solar generation is exported to government-run power distribution companies (DISCOMs). In financing SKY, central and state government each covered 30 percent of the capital cost while farmers contributed 5 percent upfront. GoG took a NABARD[5] loan to finance balance 35 percent. Net energy export would get paid US $\$ 48.61 / \mathrm{MWh}$ for next 25 years; net import would be charged at applicable subsidized rate of US $\$ 8.33 / \mathrm{MWh}$. For the first 7 years, GoG will credit additional US \$ 48.61/MWh of export (up to $1000 \mathrm{kWh} / \mathrm{HP}$ ) as EvacuationBased Incentive (EBI) towards NABARD loan repayment on farmers' behalf. For a feeder to qualify for SKY, however, at least 70 percent of the tubewell owners must join. Moreover, they also must agree to share pro rata all distribution losses above 5 percent on the SKY feeder. To make SKY attractive, adopters were offered a 'five-fold SKY benefit suit' ( hereafter, FFSBS) which included: [a] 95 percent subsidy on solar panels at a rate of $1.25 \mathrm{kWp}$ per HP of connected load[6]; [b] daytime power everyday replacing night-time power supply every alternate week; [c] 12 hours of daily power instead of 8 hours (special transformers deployed to limit supply to 8 hours for non-SKY tubewells); [d] saving of existing grid electricity tariff; and [e] extra income by hassle-free selling of surplus solar power. Additionally, SKY applicants were permitted to increase their existing load and claim more subsidized panels.

By December 2020, when SKY was terminated, 91 feeders with $97.8 \mathrm{MW}$ solar capacity and 4215 SKY tubewells (with 68180 HP load) were commissioned. Though smaller than planned, SKY turned out way 
larger than other known projects anywhere of grid-connected solar pumps. Similar pilots in India SuryaRaitha in Karnataka, Vinziyanagaram feeder in Andhra Pradesh and a pilot feeder in Jaipur, Rajasthan-- are all single feeder pilots with less than 350 pumps each (Shirisath et al 2020). This paper presents the first ever assessment of SKY using granular data provided by real time, online SKY monitoring system. Section 2 situates SKY in the history of electricity-groundwater nexus in Gujarat. Section 3 tests key hypotheses about SKY impacts and shows how the SKY-model, if scaled out, can radically improve finances of DISCOMs and socio-ecology of groundwater irrigation. Section 4 shows why Government of India's PMKUSUM-C scheme, styled after SKY, will fail to take SKY to scale. Section 5 explores a way out in compulsory, free-of-cost solarisation of all tubewells. Section 6 concludes the paper.

\section{The Hard Problem of Tubewell Metering}

SKY's prime goal was to test whether farmers would willingly embrace a positive-sum model of tubewell solarisation that would benefit farmers and also liberate Gujarat from a perverse subsidy that has drained its fisc and strained its aquifers (Shah et al 2004). Wells have played a seminal role in Gujarat's irrigation history (Shah 2009). Informal groundwater markets boomed in Gujarat villages during early 1900's when enterprising farmers invested in oil engines and buried cement pipelines more to sell irrigation service than water own crops (Shah 1993; Hardiman 1998). Spread of electricity and tubewell technology after 1950's gave a fillip to water markets. Electric pumps were then metered and electricity tariff drove water price. But metering technology was primitive, costly, laborious and prone to corruption by meter readers against whom farmers frequently agitated. Utilities too loathed the high cost and logistical difficulty of metering geographically dispersed tubewells (Shah 1993). During 1980's, many states removed meters and switched to horse-power (HP) linked flat tariff. Pressure mounted to do so in Gujarat too which until 1988 recovered US \$9/MWh[7] from metered tubewell owners. Studies in Gujarat also showed that flat tariff would transform Gujarat's 142,000 private electric tubewell owners (Joshi \& Acharya 2005) from 'water lords' into owner-managers of quasi-public utilities offering to the poor affordable irrigation that government's 3500 public tubewells had failed to do (Shah 1989; Shah 1993). In 1988, Gujarat also abandoned meters and switched to flat tariff. True to the studies, surveys showed that tubewells now worked longer hours and water buyers were paying 30-50 percent less for irrigation than before (Shah 1993). Planners had assumed periodic upward revision in flat tariff to recover the cost of rising average power consumption/HP. But this was to prove easier said than done.

Flat tariffs soon proved a Faustian bargain for Gujarat as for much of India. Throughout 1990's, tubewell numbers experienced runaway increase as did power consumption/tubewell. Water sellers made hay; buyers too enjoyed lower prices and better service until groundwater began running out. Without proactive regulation of tubewell numbers and pumping hours, Gujarat got sucked into a perverse nexus in which power subsidies drove groundwater depletion which, in turn, hardened demand for more subsidy, as described in figure 1. North Gujarat, Saurashtra and Kutch experienced secular decline in groundwater levels, even as subsidies drove electricity utility towards bankruptcy. For a while,Jyotigram[8] scheme of feeder separation and farm power rationing capped subsidies as well as groundwater draft. But a million 
new tubewell connections issued after 2000 mostly to the poor nullified the gains (Shah and Chawdhury 2017).

Early 2000's witnessed a growing national resolve to meter farm power supply, even if subsidized. This was formalised in the National Water Policy (MoWR, Gol 2002), legislated in Electricity Act 2003 and specifically mandated by GERC[9] standing order in 2004 . Unmetered supply was thought to undermine energy accounting and auditing, letting DISCOMs hide inefficiency and theft as agricultural consumption (PRAYAS 2018; Gulati and Pahwa 2015, Dubash 2007). But farmers fiercely opposed metering. While most Indian states failed to even make a start, Gujarat banned issuing new unmetered connections while subsidising metered supply. Kumar et al (2021) have argued that farmer opposition to metering in India is a red herring but even 90 percent subsidy on metered supply in Gujarat (US \$ 8.3/MWh for normal and US $\$ 11.1$ /MWh for on-demand connections) failed to lure unmetered farmers to meter tubewells. A global survey by Molle and Closas (2021) shows that metering groundwater wells is resisted and frustrated by farmers not only in India but also in US, Iran, Australia, Greece, France, Italy, Syria, Jordan, Mexico, Chile and other countries for much the same reasons as in India. The survey recommends even today, as Rajadhyaksha Committee had done back in 1985 (Shah 1993), that "metering [of irrigation wells] should be avoided in the absence of adequate resources." (p.11).

Summing up years of failed metering campaign, India's Comptroller and Auditor General lamented in a 2016 report: "Despite explicit order by the regulator to meter all unmetered connections, there was absolutely no progress in this matter... due to stiff resistance offered by farmers with unmetered connections" (CAG 2016: p 101-102). As a solid vote-bank, unmetered farmers not only successfully opposed metering but also any revision of flat tariff. Against GERC-mandated tariff of US \$33.3/HP/year, these pay even today just US $\$ 9.2 / \mathrm{HP} /$ year, less than US $\$ 10.4 / \mathrm{HP}$ they paid in 1988 . To lure them to metering, metered tariff too is kept at US $\$ 8.33 / \mathrm{MWh}$, less than US $\$ 9.03 / \mathrm{MWh}$ in 1988 , when rupee was worth 10.4 times more than today![10] The deficit is made good by GoG to GUVNL[11], the holding company of DISCOMs (rows 7,8,9,10 in table 1). In 2014-15, unmetered farmers accounted for 41 percent of Gujarat's tubewells, but 49 percent of tubewell load, 71.3 percent of farm power consumption and 90 percent of farm power subsidy. An average unmetered farmer is alleged to use 3.5 times the electricity and enjoy 13 times the subsidy claimed by average metered tubewell owner, who himself pays only 10 percent of the cost to serve.

Table 1 CAG's estimate of subsidy to metered and unmetered consumers in Gujarat: 2014-5 


\begin{tabular}{|llll|}
\hline & & Metered & Unmetered \\
\hline 1 & Number of Agricultural connections & 700398 & 485144 \\
\hline 2 & Total Load (hp) & 6918616 & 6752295 \\
\hline 4 & Mean load HP/connection & 9.88 & 13.92 \\
\hline 5 & Average consumption per connected HP, kWh (2014-15) & 719 & 1833 \\
\hline 6 & Total consumption million kWh (2014-15) & 7104 & 25515 \\
\hline 7 & GERC Tariff subsidy (2014-15) US \$ million (fixed charge) & 34.44 & 33.61 \\
\hline 8 & FPPCA subsidy (2014-15) US \$ million (energy cost) & 98.75 & 247.5 \\
\hline 9 & HP based tariff subsidy (2014-15) US \$ million [12] & 0 & 916.67 \\
\hline 10 & Total subsidy-2014-15 (US \$ million) & 133.2 & 1196.6 \\
\hline 11 & Subsidy per connection 2014-15 (US \$) & 190.2 & 2468.6 \\
\hline 12 & Subsidy per connected HP (US \$) & 19.24 & 177.4 \\
\hline 13 & Subsidy per MWh consumed (Us \$) & 26.94 & 96.81 \\
\hline
\end{tabular}

In the 1980's, Gujarat had on average 8 electric tubewells per village. Flat tariffs leveraged these to expand irrigation through pro-poor water markets while posing little threat to groundwater sustainability (Shah 1993). Today, standing at the other extreme, Gujarat has 66 tubewells per village-27 unmetered and 39 metered. Social value of water markets has eroded with fewer pure water buyers compared to the 1980 's; but fiscal and environmental burden of unmetered tubewells has soared. If these were metered, Gujarat's electricity use in irrigation - and groundwater abstraction- would decline 43.4 percent, reducing subsidy pay-outs too besides the carbon footprint of irrigation. The trouble is much unmetered load is concentrated in water-stressed north Gujarat, Saurashtra and Kutch regions (Viswanathan 2014) where farmers have violently resisted metering. As Joshi and Acharya (2005:7) noted after month-long field work here: “...[in] our perception, if GEB tries to impose new meters without consulting the farmers... [such] methods are likely to fail [24]."

Tubewell metering is anathema throughout India and indeed elsewhere. Based on the notion that cost of unmetered supply far outweighs its value to farmers, agencies have proposed schemes[13] of incentivizing farmers to willingly embrace metered power supply (Gulati and Pahwa 2015; USAID, 2011; World Bank 2019). Jury is out on how successful these are in onboarding tubewell owners and changing their pumping behaviour. SKY is a far more ambitious pilot with a component of sophisticated, tamperproof remote metering of tubewells. Did SKY succeed in onboarding unmetered farmers? Is metering changing pumping behaviour? Did farmers gain from onboarding SKY? Did the 'GoG-DISCOM combine' 
(henceforth, the Utility) gain financially and otherwise? These are critical questions that the SKY monitoring system is uniquely suited to explore. Feeders selected for SKY had metered and unmetered connections earlier. After SKY, all were brought under tamper-proof, remote metering, generating real time data on four categories of agricultural connections:

- MetSol: previously metered tubewells whose owners onboarded SKY and are now subject to SKY terms under FFSBS

- FlatSol: previously unmetered flat tariff paying farmers who onboarded SKY and are now subject to FFSBS

- MetNonsol: previously metered farmers on SKY feeders who did not join SKY and continue to pay subsidized grid tariff on metered consumption

- FlatNonsol: previously unmetered tubewells on SKY feeders who did not join SKY; these are now metered but continue to pay HP-linked flat tariff regardless of metered consumption

Our analysis in the remainder of this paper is based on this dataset.

\section{Early Insights from SKY}

\subsection{SKY Adoption Rates}

For metered farmers, benefits of SKY are obvious. They are metered anyways; and getting Five Fold Sky Benefit Suit (FFSBS) against contributing just 5 percent of capital cost is a lucrative deal for them. But for unmetered farmers, decision is not so clear cut given that it is irreversible. Is joining SKY worth permanently giving up average subsidy of US $\$ 2468 /$ year (CAG 2016) for a lifetime? We therefore expected lukewarm response to SKY from unmetered farmers compared to metered ones. But SKY results are surprising (figure 2) since the onboarding ratio is nearly the same at 66-69 percent for both metered and unmetered tubewell owners.

Did hydrogeology have any influence on farmer decision to join SKY? To explore this, we need to disaggregate onboarding rates across regions. Figure 3 shows service areas of Gujarat's four DISCOMs, each with distinct hydrogeological profile. DGVCL[14] serves humid-alluvial south Gujarat amply recharged by rainfall and canals. MGVCL serves semi-arid central and eastern Gujarat with alluvial and hard-rock aquifers recharged by canals and modest rainfall. UGVCL serves arid North-Gujarat with stressed alluvial aquifers, and limited recharge sources while PGVCL serves semi-arid Saurashtra with karst aquifers and arid Kutch's alluvial aquifers. Gujarat's energy-water nexus plays out fully in service areas of PGVCL and UGVCL, which account for 90 percent of its unmetered load (Viswanathan 2014:24) as well as of agricultural power consumption (CAG 2016) (table 2). SKY onboarding ratio matters far more in PGVCL and UGVCL than in DGVCL and MGVCL.

Table 2 Agricultural Power Consumption Across Gujarat DISCOMs (CAG 2016:149-150) 


\begin{tabular}{|clllll|}
\hline & DGVCL & MGVCL & PGVCL & UGVCL \\
\hline 2 & Level of groundwater development & low & moderate & high & high \\
\hline 3 & $\begin{array}{l}\text { Agricultural power consumption in 2014-15 } \\
\text { (million kWh) (\% share in Gujarat total) }\end{array}$ & 857 & 1233 & $\begin{array}{l}10134 \\
(47)\end{array}$ & $\begin{array}{l}9222 \\
(43)\end{array}$ \\
\hline $4 \begin{array}{l}\text { \% share in Gujarat's Unmetered } \\
\text { Agricultural Load }\end{array}$ & 3.7 & 4.2 & 38.6 & 53.5 \\
\hline $\begin{array}{l}\text { \%oshare in Gujarat's Metered Agriculture } \\
\text { Load }\end{array}$ & 7.5 & 11.1 & 51.4 & 29.9 \\
\hline $\begin{array}{l}\text { Metered consumption as \% of agricultural } \\
\text { power consumption }\end{array}$ & 37 & 22.5 & 21.8 & 20.3 \\
\hline
\end{tabular}

Table 3 shows SKY onboarding rates to hoover between 61-73 percent across DISCOMs, the only exception being UGVCL where surprisingly, 88 percent of unmetered tubewell owners embraced SKY. It was in UGVCL villages that Joshi and Acharya (2005) had reported on acrimonious, even violent, threats against tubewell metering. Given that many innovative schemes to incentivize farmers to accept meters have been frustrated by poor farmer response (Kishore et al. 2004:1; Gulati and Pahwa 2015, Mishra 2004; Fishman et al 2016), SKY's success in onboarding unmetered tubewell owners in north Gujarat, Saurashtra and Kutch is remarkable even though most feeders failed to meet the minimum 70 percent onboarding criterion. SKY suggests that, with a well-designed and aggressive Education, Information and Communication (EIC) campaign, solarisation can arguably meter Gujarat out of its invidious energy-water nexus.

Table 3 SKY Onboarding Rate Across Four Gujarat DISCOMs; 5934 Tubewells on SKY feeders

\begin{tabular}{|llllll|}
\hline & & $\begin{array}{l}\text { DGVCL } \\
\text { (South) }\end{array}$ & $\begin{array}{l}\text { MGVCL } \\
\text { (Central) }\end{array}$ & $\begin{array}{l}\text { PGVCL } \\
\text { (West) }\end{array}$ & $\begin{array}{l}\text { UGVCL } \\
\text { (North) }\end{array}$ \\
\hline 1 & Total tubewells on SKY feeders & 713 & 876 & 1715 & 627 \\
\hline 2 & $\begin{array}{l}\text { \% of metered tubewells solarised under } \\
\text { SKY }\end{array}$ & 72.7 & 68.0 & 67.2 & 69.7 \\
\hline $\begin{array}{l}\text { \% of unmetered tubewells solarised under } \\
\text { SKY }\end{array}$ & 64.7 & 60.8 & 61.5 & 88.2 \\
\hline
\end{tabular}


An important but unsettled question around unmetered tubewell owners is: do they really consume significantly more power/HP than metered consumers or is their alleged excess consumption a fig-leaf to conceal distribution losses, theft and inefficiency (Dubash 2007; PRAYAS 2018). Until now, there was no way of knowing the answer. With SKY data on metered consumption, for the first time we can now test this hypothesis because we have data on MetNonsol and FlatNonsol farmers who are not affected by FFSBS except by year-round daytime power supply they did not enjoy earlier. If unmetered tubewells are used to hide losses and theft, there should be no significant difference between metered consumption/HP of MetNonsol and FlatNonsol farmers. Table 4 compares SKY data and GERC numbers used by CAG(2016) to examine this question. This strongly supports the 'excess consumption hypothesis' with the ratio of unmetered to metered consumption per HP remarkably similar at around 2.55 for both data sets. This makes $1850 \mathrm{kWh} / \mathrm{HP}$ a credible estimate of consumption by unmetered farmers since 718 kWh/HP/year used by CAG (2016) is metered consumption of metered farmers.

Table 4 Power consumption by metered and unmetered tubewells: Comparing CAG estimates with SKY metered data

\begin{tabular}{|llllll|}
\hline & $\begin{array}{l}\text { Number } \\
\text { of } \\
\text { tubewells }\end{array}$ & $\begin{array}{l}\text { Average } \\
\text { load/ } \\
\text { connection } \\
\text { (HP) }\end{array}$ & $\begin{array}{l}\text { Average } \\
\text { solar } \\
\text { generation } \\
\text { (kWh/HP/ } \\
\text { year) }\end{array}$ & $\begin{array}{l}\text { Average } \\
\text { annual } \\
\text { consumption } \\
\text { (kWh/HP/ } \\
\text { Year) }\end{array}$ & $\begin{array}{l}\text { Ratio of } \\
\text { consumption by } \\
\text { unmetered to } \\
\text { metered } \\
\text { tubewells }\end{array}$ \\
\hline $\begin{array}{l}\text { CAG 2016: } \\
\text { Metered }\end{array}$ & 700398 & 9.9 & 0 & 718 & 1 \\
\hline $\begin{array}{l}\text { CAG 2016: } \\
\text { Unmetered }\end{array}$ & 485144 & 13.9 & 0 & 1835 & 2.56 \\
\hline MetNonsol & 901 & 16.7 & 0 & 393 & 1 \\
\hline FlatNonsol & 251 & 19.3 & 0 & 993 & 2.53 \\
\hline
\end{tabular}

A regression of consumption/tubewell on connected load (HP)/tubewell and dummy variables for unmetered connections (UD) in each DISCOM showed large and statistically significant coefficients for dummy variables in all DISCOMs except DGVCL:

Consumption/connection = 123.6 + $942($ UD- DGVCL) $+7029($ UD-MGVCL+ 9554(UD-UGVCL) + $[0.47] \quad[0.86] \quad[7.48] \quad[7.82]$

10193(UD-PGVCL)+ 462.5 (HP-CONNECTED LOAD)

[15.57]

[43.97]

$\mathrm{R}^{2}=0.421 ;$ Adjusted $\mathrm{R}^{2}=042 ;$ No. of observations $=3666$ 
This too supports the 'excess consumption' thesis. It predicts mean consumption/HP for metered tubewells to be $471 \mathrm{kWh}$ across DISCOMs; but for unmetered tubewells, it predicts $533 \mathrm{kWh} / \mathrm{HP}$ in DGVCL, 939 kWh/HP in MGVCL, 1108 kWh/HP in UGVCL and 1150 kWh/HP in PGVCL. Figure 4 plots log values of consumption/HP against connected load. FlatSol and FlatNonsol tend to hoover towards the top suggesting excess consumption to be the central behavioural tendency of unmetered connections.

One unexpected finding is that average metered consumption/HP for FlatNonsol and MetNonsol on SKY feeders is less than half of CAG (2016) numbers for Gujarat overall (table 4). Does this mean that even metered consumption is overstated to the extent of 100 percent on non-SKY feeders? No so. We posit that SKY feeders show lower consumption/HP because: [a] these were carefully chosen for low line losses; [b] they have higher proportion (79.6 percent) of metered connections than state average (59.3 percent); [c] table 4 shows actual consumption for SKY tubewells while CAG (2016) reports power sent including transmission and distribution losses which are higher than 50 percent on some feeders in PGVCL and UNGVCL; and [d] table 4 gives equal weightage to all four DISCOMs while PGVCL and UGVCL have overwhelming share in farm power consumption, unmetered load and distribution losses.

We expected that under SKY power consumption/HP by FlatSol will move away from FlatNonsol and closer to that of MetSol because FlatSol are now metered and can sell surplus energy to the grid at remunerative price. In actuality, however, FFSBS puts conflicting pressure on consumption/HP by SKY tubewell owners: [a] moving from 8 hours of day-and-night power earlier to 12 hours of daytime power every day is expected to exert a strong 'supply push', making possible increased consumption than before; [b] on the other hand, saving power and selling it at US $\$ 48.6 / \mathrm{MWh}$ is expected to create a 'demand pull' for reducing consumption. Table 5[15] and figure 5 present the confusing picture that results at the end of 1 year of SKY. MetSols' 17 percent higher consumption/HP over MetNonsol reflects 'supply push' that overwhelmed 'demand pull'. FlatSol, on the other hand, consumed 16 percent less than FlatNonsol but way more (83 percent) than MetSol who they were expected to mimick. Does this disprove the SKY hypothesis? We think not. FlatNonsol consumed 2.57 times more than MetNonsol while FlatSol consumed only 1.83 times that of MetSol, suggesting that FlatSol:MetSol ratio is inching towards 1. Given that hours of available power is critical during peak irrigation season, it is noteworthy that SKY adopters are using much less of potentially available power/HP compared to non-adopters (last column). It is also likely that FlatSol are unable to shake off abruptly the overhang of a decades-old water selling tradition and desert an established, loyal clientele, reneging on their commitments. There was also much uncertainty about getting paid for energy until they got the first check from the Utility at year-end when the 'demand pull' to save energy would kick in. Clearly, there is an adjustment process in motion that will work itself out gradually.

Table 5 Pumping behaviour of four classes of tubewell owners on SKY feeders: Total connections 5934 on 69 feeders completed by January 2020 


\begin{tabular}{|lllll|}
\hline & $\begin{array}{l}\text { Number } \\
\text { of } \\
\text { tubewells }\end{array}$ & $\begin{array}{l}\text { Average } \\
\text { annual } \\
\text { consumption } \\
\text { (kWh/HP/ } \\
\text { Year) }\end{array}$ & $\begin{array}{l}\text { Ratio of unmetered to } \\
\text { metered consumption/ HP } \\
\text { for solar and non-solar } \\
\text { tubewells }\end{array}$ & $\begin{array}{l}\text { Mean daily } \\
\text { consumption/HP } \\
\text { per available } \\
\text { power hour }(\mathrm{kWh})\end{array}$ \\
\hline MetSol & 2230 & 459 & & 0.106 \\
\hline MetNonsol & 901 & 393 & & 0.136 \\
\hline FlatSol & 549 & 841 & 1.83 & 0.195 \\
\hline FlatNonsol & 251 & 993 & 2.57 & 0.345 \\
\hline
\end{tabular}

In a dozen feeders commissioned in 2018, SKY data available for 2019 and 2020 show (in figure 5) that while consumption/HP of MetSol owners increased by 5 percent, that for FlatSol decreased 28.7 percent. 9 out of 12 feeders showed a decline in consumption for MetSol as well as FlatSol. The 3 feeders where it rose were all in PGVCL which experienced a drought in 2020. We also have, for peak irrigation months of February to April, data for 2019,2020 and 2021 for these early 12 feeders (figure 6). During 2020, 'supply push' of 12 hours/day of daytime power led all tubewell owners to increase consumption. But after the first annual payment for energy sales was made in May 2020, MetSol and FlatSol steeply reduced consumption by 26.1 and 34.1 percent respectively. This suggests that FlatSol consumption/HP is tending towards that of MetSol at a pace tempered by an adjustment parameter.

Table 6 Pumping behaviour of four classes of tubewell owners on SKY feeders: Comparing across DISCOMs

\begin{tabular}{|clllll|}
\hline & & DGVCL & MGVCL & PGVCL & UGVCL \\
\hline 1 & Total number of tubewells on SKY feeders & 713 & 876 & 1715 & 627 \\
\hline 2 & Annual consumption kWh/HP: MetSol & 738 & 607 & 405 & 381 \\
\hline 3 & Annual consumption kWh/HP: MetNonsol & 445 & 510 & 451 & 274 \\
\hline 4 & annual consumption kWh/HP: FlatSol & 668 & 871 & 848 & 836 \\
\hline 5 & annual consumption kWh/HP: FlatNonsol & 692 & 932 & 998 & 1116 \\
\hline
\end{tabular}

Table 6 suggests that our core SKY hypothesis-that consumption/HP of unmetered tubewells will decline under SKY as they become FlatSol-has stronger support in PGVCL and UGVCL where it matters most and weak support in DGVCL and MGVCL where it matters the least. The decline in consumption/HP of FlatSol farmers is higher in PGVCL (18 percent) and UGVCL (33 percent) which are the locus of Gujarat's energy-water nexus. The decline is marginal in DGVCL (4 percent) and MGVCL (6 percent) 
whose share in Gujarat's agriculture load is minuscule. If SKY is to be mainstreamed, PGVCL and UGVCL should take the lead.

\subsection{Farmers' Gain from onboarding SKY}

SKY farmers can use the same amount of power/HP they used earlier for irrigation and water selling without paying grid power tariff; and they also have the new option to sell energy saved which they could not do earlier. Farmers' incremental gain from onboarding SKY then is the value of surplus power exported plus grid power tariff saved less payment for net energy import (if any). Of 2997 SKY farmers' clean records we found to estimate incremental gains in the first year, 2608 (87 percent) exported energy while 389, mostly FlatSol owners in DGVCL, were net importers. These had to pay for energy import but could have earned more from water selling.

Figure 7 shows farmers' incremental gains/HP from joining SKY. Overall, MetSol gained more per HP because they pumped less and exported more compared to FlatSol; but some FlatSol might have earned more by selling water which figure 7 fails to capture. Earnings/tubewell from energy sales, however, are much higher for FlatSol simply because they had larger connected load (figure 8). In both figures, DGVCL is an outlier with both FlatSol and MetSol owners ending up net energy importers but DGVCL is insignificant player in Gujarat's energy-irrigation nexus.

The incremental gains to farmers are large enough to pay back their 5 percent capital contribution[16] in the first year itself. Benefit-Cost ratio (BCR)[17] for farmer investment of US \$39.1/HP to onboard SKY is 6.03 for unmetered farmer and 8.8 for metered ones. BCR would be even higher had incremental gain/HP for GUVNL been computed giving 90 percent weightage to PGVCL and UGVCL where gain/HP is much higher. For farmers, SKY has made solar energy a lucrative crop with no production or marketing costs. According to NABARD, average monthly farm household income in 2017 was US \$ 124 for India and US \$ 165.3 for Gujarat. Gains from SKY constitute 47 percent to Gujarat's farm household income (Tol 2020). Onboarding farmers on SKY could do half the job of 'doubling farm incomes', that present government of India swears by.

Figure 9 plots energy consumption as percent of solar generation by SKY tubewells. Overall, MetSol consumed 29.2 percent while FlatSol consumed 48.5 percent (Figure 9). Dhundi and Mujkuva-the two village-scale pilots that inspired SKY -had 33 and 38.6 percent consumption ratio against FiT of US $\$$ 64.3/MWh and US \$ 48.6/MWh respectively; but unlike SKY tubewells neither of these have net-metered tubewells; farmers here pump only with solar power. In Karnataka's Surya Raitha scheme, the consumption ratio is 67 percent (KERC 2017) despite 1.5 times panel oversizing and feeder line kept live 12 hours daily. The reason, presumably, was a low FiT of US $\$ 13.9 / \mathrm{MWh}$ and even that remained unpaid. The relatively low consumption ratio in SKY was a combined impact of enhanced load, 1.25 times panel oversizing and remunerative FiT of US \$ 48.6/MWh.

\subsection{Gains from SKY: Perspective of the Utility}


SKY promised a positive sum outcome in which farmers as well as the Utility gain. Incremental financial gains for the Utility from a tubewell migrating to SKY is

$=[\mathrm{A}]+[\mathrm{B}]-[\mathrm{c}]$, where

$[A]=$ saved cost of serving grid power inclusive of distribution losses

$[B]=$ savings in solar power purchase and

$[C]=$ current tariff lost.

In computing overall gains to the Utility in figure 10, we assumed GERC-approved cost of grid power at US \$ 81.9/MWh 2020-21 [18] , computed lost tariff by Utlity at US \$ 8.3/ MWh for MetSol and US\$ 9.2/HP/year for FlatSol owners; assumed 20 percent distribution losses saved when SKY farmers selfproduce energy instead of using grid supply and only 5 percent line losses are borne by DISCOMs on solar energy injected by farmers. Savings in line losses are substantial and real. Vala (2021) showed that average distribution loss on 79 SKY feeders declined from 24 percent earlier to 7.46 percent 12 months into SKY; and of this, DISCOMs would bear only 5 percent. SKY feeders will likely have the lowest line losses on agricultural feeders anywhere in India.

For comparison sake, figure 10 also presents losses incurred by Utility on MetNonsol and FlatNonsol tubewells on SKY feeders. Every tubewell migrated to SKY implies losses avoided plus new gains made. Once again, figure 10 understates true gains/HP because it does not give 90 percent weightage to PGVCL and UGVCL where gains/HP are higher (figure 11). SKY feeders were chosen for low line losses, high metering ratio and low grid power consumption/HP compared to an average agricultural feeder. The Utility's gains would be substantially higher when SKY is mainstreamed to onboard metered and unmetered tubewells that draw around $719 \mathrm{kWh} / \mathrm{HP}$ and $1855 \mathrm{kWh} / \mathrm{HP}$ respectively (CAG 2016 estimates) instead of SKY average consumption of 393 and $993 \mathrm{kWh} / \mathrm{HP}$ respectively. On GoG investment of US $\$ 511.1 / \mathrm{HP}$ on SKY subsidy[19], the BCR is 1.71 for unmetered tubewells and 1.25 for metered tubewells. BCR will increase as consumption/HP for MetSol and FlatSol decline further over time as the 'adjustment process' works itself out. Finally, to the financial BCR, we need to add SKY's nonfinancial gains including the value of [a] Renewable Energy Certificates; [b] gains in improved energy (and groundwater) accounting and auditing; [c] value of a new potent instrument for groundwater governance.

To conclude, SKY has proved a win-win proposition for all stakeholders. Its many objectives were to [a] ensure daytime quality power to farmers; [b] reduce tariff subsidy burden on government and crosssubsidising consumers; [c] contribute to National Solar Mission; [d] promote distributed solar generation; [e] reduce distribution losses and [f] provide farmers a secondary source of income (Vala 2019). SKY delivered on all these. In addition, it also succeeded in metering unmetered tubewells, something governments and regulators have struggled to do for 20 years without success. SKY thus emerges as a model for Indian states and other countries where unmetered power supply frustrates sustainable water- 
energy governance (Molle and Closas 2021). SKY farmers not only embraced metering but got their skin in the metering process. SKY feeders show evidence of farmers' concern, never heard of before, to ensure that meters function well, and with minimum downtime. On a separate note, in promoting distributed solar generation, SKY underscores distinct superiority of farm-top solar over roof-top solar promoted aggressively under SURYA-Gujarat scheme that allows premium consumers to escape peak slab in the telescopic tariff structure. SKY benefits consumers as well as Utility; SURYA-Gujarat benefits only the consumer, hurtling the DISCOMs towards the dreaded 'utility death syndrome' (Lacy, 2014; Sythoff 2019). All these make a strong case for mainstreaming and scaling out SKY to solarize Gujarat's 10.3 GW (CAG 2016) of grid-connected tubewell load and for adapting its lessons to other states.

\section{PMKUSUM-C: will it scale out SKY?}

In November 2020, GoG abruptly discontinued SKY and announced new guidelines under Government of India's US \$ 7.7 billion Prime Minister's Krishi Urja Suraksha evam Utthaan Mahabhiyan[20] (PMKUSUM) scheme whose component $C$ is inspired by Dhundi cooperative (Jayan 2018) and styled after SKY. But the new guidelines are palpably less attractive than SKY's FFSBS (table 7). They offer only 8 hours/day of daytime power, a FiT of US $\$ 39.3 / \mathrm{MWh}$, ask farmers to find their own funds to contribute 40 percent of the capital cost. These together will make it impossible to onboard 70 percent tubewells on each feeder, making PMKUSUM-C a non-starter.

Table 7 Comparing 'Five-fold SKY benefit suit’ (FFSBS) with KUSUM-C Gujarat Guidelines

\begin{tabular}{|llll|}
\hline & \multicolumn{1}{|c|}{$\begin{array}{l}\text { SKY: five-fold SKY benefit } \\
\text { suit(FFSBS) }\end{array}$} & $\begin{array}{l}\text { KUSUM-C Gujarat } \\
\text { guidelines[21] }\end{array}$ \\
\hline 1 & $\begin{array}{l}\text { Solar panels offered } \mathrm{kWp} / \mathrm{kW} \\
\text { connected load }\end{array}$ & 1.67 times & 1.75 times[22] \\
\hline 2 & $\begin{array}{l}\text { Farmer upfront contribution to } \\
\text { capital cost }\end{array}$ & $5 \%$ & $80 \%$ \\
\hline 3 & $\begin{array}{l}\text { Hours of day-time power } \\
\text { supply }\end{array}$ & 12 hours \\
\hline 4 & $\begin{array}{l}\text { Saving in grid power tariff } \\
5\end{array}$ & $\begin{array}{l}\text { Feed-in-Tariff (FiT) (US \$ / } \\
\text { MWh) }\end{array}$ & US\$ 48.6/MWh \\
\hline 6 & $\begin{array}{l}\text { Minimum participation to } \\
\text { solarise a feeder }\end{array}$ & $70 \%$ & US \$ 39.3/MWh \\
\hline
\end{tabular}

For farmers to embrace PMKUSUM-C en masse, its offering must not only seem better than choosing status quo but also have the power to nudge farmers out of the lethargy that made $1 / 3^{\text {rd }}$ farmers on SKY feeders forgo the highly attractive FFSBS. The barriers that produced lethargy were diverse. Many 
farmers were not sure if they would actually get paid for solar power. Psychological barrier of loss aversion--"bird in the hand is worth two in the bush" (Kahneman \& Tversky, 1979)-drove many to choose status quo, especially because the decision to join SKY was irreversible. Absentee farm-owners had no interest and their tenants had no power to join SKY. Many small and marginal farmers lacked ready capital or credit-worthiness to make even 5 percent upfront capital contribution. These and other such barriers will undermine PMKUSUM-C, too. To succeed, PMKUSUM-C needs to nudge tubewell owners to overcome these barriers, brush aside lethargy and solarise en masse.

\section{Compulsory, Free-of-cost Solarisation of Tubewells}

One way to meet this challenge is by revisiting panel oversizing ratio of $1.75 / \mathrm{kW}$ load that requires farmers to contribute significant capital upfront. Oversizing panels was necessary in Dhundi and Mujkuva solar pilots to run pumps in low light of mornings and evenings. In Andhra Pradesh solar pilot, highly efficient brushless DC (BLDC) pumps achieved the same result without oversized panels (Sirisath et al 2020). However, in Gujarat's conception of PMKUSUM-C, as in SKY, pumps are to run on grid power; here oversizing panels is not a technical compulsion but an economic incentive. Farmer can claim subsidy of US $\$ 436.7 / \mathrm{HP}$ on panels by investing US \$290.8/HP and, over 25 years' economic life, generate attractive net present value (NPV) of US \$ 410/HP[23] with a benefit-cost ratio (BCR) of 2.41. This is very profitable but may not lure heavy users of unmetered grid power for whom the BCR of status quo is infinity and NPV, around US \$916.7/HP.[24] Moreover, substantial upfront contribution required to join PMKUSUM-C is sure to repel capital-short or credit unworthy farmers, unwilling absentee tubewell owners, and risk-averse farmers suffering 'loss aversion'.

Recent pilots on grid-connected solar pumps suggest that capital contribution drives farmers' onboarding rate and FiT drives their energy evacuation rate. In the Andhra Pradesh pilot as well as Karnataka's Surya Raitha pilot, farmers enjoyed unmetered, free grid power; yet DISCOMs onboarded 100 percent farmers by assuring: [a] zero farmer contribution to capital; and [b] free power supply as before or better. In SKY too, informal interviews indicated that close to 100 percent farmers would have joined had the Energy Minister abolished upfront farmer contribution altogether as farmers demanded instead of reducing it from 10 to 5 percent. Given this experience, there is a case for PMKUSUM-C is to launch a time-bound campaign for compulsory, free-of-cost solarisation of all grid-connected tubewells. Like compulsory free primary education, compulsory solarisation will be accepted easily only if it is offered free than if farmers are asked to share capital cost. In specific terms, GoG should:

[A] present existing guidelines (column 1 in table 8 ) as the first option (PMKUSUM-COI) to metered and unmetered farmers;

[B] offer a second option, PMKUSUM-COII (col. 2 in table 8), which will provide, free-of-cost, solar panels of $0.75 \mathrm{kWp} / \mathrm{HP}$ of connected load (complete with net metering installation) to all tubewell owners, consistent with recent GoG policy of providing $3.75 \mathrm{kWp}$ subsidised solar panels for $5 \mathrm{HP}$ off-grid pumps. All other terms will remain the same as in PMKUSUM COI. 
[C] to farmers choosing PMKUSUM-COII, provide 60 percent subsidy on additional panels up to the limit imposed by PMKUSUM-COI.

[D] resolve to compulsorily meter all remaining unmetered tubewells at the end of a specified transition period (by say December 31, 2023) beyond which all farm power supply in Gujarat will be metered and charged at the solar FiT of US $\$ 39.3 / \mathrm{MWh}$ or current metered tariff of US $\$ 8.3 / \mathrm{MWh}$, as determined by GERC.

If SKY data are any guide, consumption/HP will decline sharply in response to a FiT of Rs $2.83 / \mathrm{kWh}$. At solar generation of $1500 \mathrm{kWh} / \mathrm{kWp} /$ year, $0.75 \mathrm{kWp} / \mathrm{HP}$ of solar panel will offer $1150 \mathrm{kWh} / \mathrm{HP} /$ year (equivalent to $1438 \mathrm{kWh} / \mathrm{HP}$ of grid supply) and exceed consumption/HP of most tubewell owners. Figure 12 shows that those using less than $1000 \mathrm{kWp} / \mathrm{HP}$ stand to gain significantly from PMKUSUMCOIl; those using more than 1250 will lose if they have to pay US $\$ 39.3 / \mathrm{MWh}$ for net import. But if GERC mandates, as it did with SKY, that net imports must be charged at prevailing metered tariff of US $\$$ 8.3/MWh, then onboarding PM-KUSUM-COIl becomes profitable for all farmers bar very few who are currently sent out more than $2800 \mathrm{kWh} / \mathrm{HP}$ of grid power. The option to buy more panels at 40 percent subsidy will enhance acceptability of PMKUSUM-COIl among these as will the high transaction costs of selling water versus selling electricity. The fact that an overwhelming majority will gain from PMKUSUMCOII will also mute opposition to compulsory solarisation from fringe cases.

Table 8 Two Proposed Options in PMKUSUM-C to Appeal to Different Segments of Farmers

\begin{tabular}{|lll|}
\hline & $\begin{array}{l}{[1]} \\
\text { PMKUSUM-CO I }\end{array}$ & $\begin{array}{l}{[2]} \\
\text { PMKUSUM-CO II }\end{array}$ \\
\hline $\begin{array}{l}\text { Panel (kWp) to load (HP) (P/L) } \\
\text { ratio }\end{array}$ & $1.31 \mathrm{kWp} / \mathrm{HP}$ & $0.75 \mathrm{kWp} / \mathrm{HP}$ \\
\hline MNRE subsidy & $30 \%$ & $30 \%$ \\
\hline GoG subsidy & $30 \%$ & $70 \%$ \\
\hline Farmer contribution & $40 \%$ & 0 \\
\hline FiT (US \$/MWh) & 39.3 & 39.3 \\
\hline $\begin{array}{l}\text { Tariff on net energy import (US } \\
\text { \$MWh) }\end{array}$ & $\begin{array}{l}39.3 \text { or } 8.3 \text { as GERC } \\
\text { mandates }\end{array}$ & $\begin{array}{l}39.3 \text { or } 8.3 \text { as GERC } \\
\text { mandates }\end{array}$ \\
\hline Daily daytime power hours & 8 & 8 \\
\hline
\end{tabular}

Despite paying for $0.75 \mathrm{kWp} / \mathrm{HP}$ of panels, the Utility will gain financially with every tubewell migrating to PMKUSUM COI or COIl as explored in table 9. This summarises from annexure 1 gains to Utility and 
tubewell owner from migrating a $15 \mathrm{HP}$ tubewell to PMKUSUM-COI and COII. Key assumptions made are: [a] for 25 years' economic life of solar pumps, unmetered connections will pay the prevailing HP linked tariff of US \$9.2/HP/year and metered connections will pay US \$ 8.3/MWh; [b] marginal productivity of electricity in irrigation or water sale is US $\$ 55.6 / \mathrm{MWh}$; [c] average unmetered and metered connection is sent $1855 \mathrm{kWh} / \mathrm{HP}$ and $719 \mathrm{kWh} / \mathrm{HP}$ of grid power respectively annually(CAG 2016); [d] average distribution loss on agriculture feeders is 20 percent; [e] upon migration to PMKUSUM-C with the option to sell surplus energy at US $\$ 39.3 / \mathrm{MWh}$, FlatSol farmers take three years of 'adjustment process' to begin behaving as if operating as MetSol farmer; [f] MetSol farmers' power consumption/HP after solarization remains $575 \mathrm{kWh} / \mathrm{HP}$ (719 kWh/HP of grid power sent less 20 percent losses) despite attractive FiT of US $\$ 39.3 / \mathrm{MWh}$; $\mathrm{g}$ ] cost to serve grid power is US $\$ 81.9 / \mathrm{MWh}$; [f] the cost of solarisation is US $\$$ $555.6[25] / \mathrm{kWp}$, average solar generation is $1500 \mathrm{kWh} / \mathrm{kWp} /$ year and discount rate applicable is 10 percent/year. The workings presented in table 9 are for the representative tubewell owner and would change as consumption/HP before and after migration changes. Payback period in column $A$ is for farmer investment and B for combined investment of GoG and MNRE in solar subsidy.

Table 9 Gains (US \$) of Migrating 15 HP Tubewell to PMKUSUM-CoI and PMKUSUM-COII 


\begin{tabular}{|c|c|c|c|}
\hline & & {$[\mathrm{A}]$} & [B] \\
\hline & & $\begin{array}{l}\text { NPV of } \\
\text { Gains } \\
(+) / \text { Loss }\end{array}$ & $\begin{array}{l}\text { NPV of gains }(+) / \text { Loss }(-) \text { to } \\
\text { Utility (US } \$ / 15 \mathrm{HP} \text { tubewell) }\end{array}$ \\
\hline & & $\begin{array}{l}(-) \text { to } \\
\text { Consumer }\end{array}$ & \\
\hline & & $\begin{array}{l}\text { (US \$/15 } \\
\text { HP } \\
\text { tubewell) }\end{array}$ & \\
\hline 1 & $\begin{array}{l}\text { Continuing with } 15 \mathrm{HP} \text { unmetered tubewell for } 25 \\
\text { years }\end{array}$ & +12597 & -19167 \\
\hline 2 & Migrating $15 \mathrm{HP}$ unmetered tubewell to & +7458 & +23944 \\
\hline & PMKUSUM-COI [payback period] & $\begin{array}{l}{[40.3} \\
\text { months] }\end{array}$ & [26.2 months] \\
\hline 3 & Migrating $15 \mathrm{HP}$ unmetered tubewell to $(0.75 \mathrm{kWp} / \mathrm{HP})$ & +10333 & +17917 \\
\hline & 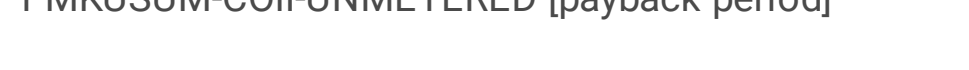 & [0 months] & [30.5 months] \\
\hline 4 & Continuing with $15 \mathrm{HP}$ metered tubewell for 25 years & +5417 & -7181 \\
\hline 5 & Migrating $15 \mathrm{HP}$ metered tubewell to & +7458 & +11972 \\
\hline & PMKUSUM-COI [payback period] & $\begin{array}{l}{[40.3} \\
\text { months] }\end{array}$ & [46.8 months] \\
\hline 6 & Migrating $15 \mathrm{HP}$ metered tubewell to $(0.75$ & +10333 & +5958 \\
\hline & & [0 months] & [66 months] \\
\hline 7 & Providing three $5 \mathrm{HP}$ solar pumps in lieu of metered & +4097 & +3125 \\
\hline & & $\begin{array}{l}{[7.9} \\
\text { months] }\end{array}$ & [89.9 months] \\
\hline
\end{tabular}

Key take-aways from table 9 are: [a] grid power subsidy creates a negative sum game with the Utility losing much more than farmers' financial gain (rows 1 and 4); (besides imposing substantial environmental cost on society) [b] unmetered tubewells cost the Utility much more than twice in subsidy than metered tubewells (B1 and B4); [c] migrating every tubewell, metered or unmetered, to PMKUSUM COI or COIl leaves the Utility better off; [d] it also leaves all metered and many unmetered tubewell owners better off than now; [e] PMKUSUM-COI is more beneficial than PMKUSUM-COII for the Utility, but less so for farmers who will prefer the latter since it entails no upfront investment; [e] only unmetered tubewell owners with high current grid power consumption are better off in status quo than migrating to PMKUSUM-C; however, even these will be better off with PMKUSUM-COII (A3) than with subsidized but metered grid power supply (A4). 
During recent years, GoG has provided 95 percent subsidy at a rate of $0.75 \mathrm{kWp} / \mathrm{HP}$ on some 3500 offgrid solar pumps[26] provided in lieu of metered grid connections. The objective was to avoid future subsidy pay-outs on grid power (B7). In comparison, 100 percent panel subsidy on $0.75 \mathrm{kWp} / \mathrm{HP}$ as proposed here under PMKUSUM-COII has even stronger justification since future subsidy pay-outs saved on legacy unmetered tubewells are 2.5 times larger per HP and 4-5 times larger per connection. Moreover, it is easier to impose compulsory solarisation when farmers pay nothing than when they are asked to share the cost of solarisation.

\section{Conclusion and Way Forward}

The heart of the problem discussed in this paper is the political economy of farm power subsidies in Gujarat. Metering all tubewells can, all at once, snap open this grid lock, drastically reducing subsidy burden, groundwater draft and energy use in irrigation. However, given farmer opposition to metering, this obvious solution has remained on paper all these years and will remain so in foreseeable future in Gujarat. This is even more true of other Indian states where al/ tubewells are unmetered.

The SKY monitoring system showed that: [a] unmetered farmers were as enthusiastic as metered ones about onboarding SKY; [b] unmetered farmers who onboarded SKY began to sharply reduce their power consumption/HP once payment for energy began kicking in; [c] this behaviour change was pronounced in groundwater-stressed PGVCL and UGVCL areas which are the locus of Gujarat's electricity-groundwater nexus; and [d] despite paying for 95 percent of capital cost, the Utility stands to gain financially from SKY as do farmers. It follows that compulsory free solarisation of all tubewells can arguably present a mutually gainful way out of this invidious political economy, making winners out of farmers, utility, climate and environment..

Current PMKUSUM-C guidelines are unlikely to onboard farmers en masse. At $1.75 \mathrm{kWp} / \mathrm{kW}$ load, solarising Gujarat's 13.7 million HP of tubewell load would entail an outlay of US \$ 10 billion[27] of which farmers are to contribute US $\$ 4$ billion. Farmers are unlikely to make such contribution, not because PMKUSUM-C is not profitable for them, but because they already enjoy lucrative grid power subsidy they know cannot be taken away. PMKUSUM-COIl proposed here for compulsory free solarisation of $5.2 \mathrm{GW}$ of metered and $5.1 \mathrm{GW}$ of unmetered tubewell load (CAG 2016) entails an investment of US $\$ 5.7$ billion with GoG share of US \$ 3.9 billion. From table 9, the net present value (NPV) of the Utility's gain over 25 years from migrating unmetered and metered tubewells to PMKUSUM COII is US $\$ 1592.6 / \mathrm{kWp}$ and US $\$$ $529.6 / \mathrm{kWp}$ respectively. Aggregate NPV of gains from compulsory solarisation of Gujarat's $10.3 \mathrm{GW}$ of agricultural load is US $\$ 10.88$ billion, offering a lucrative BCR of over 2.9. Compulsory, free-of-cost solarisation will be highly profitable for the Utility as well as farmers.

The proposal has other benefits. In 2020, GoG also announced Suryodaya, a new pro-farmer scheme of providing farmers daytime grid power year-round. This will not only increase peak-load but also transmission and distribution losses. Compulsory, free-of-cost tubewell solarisation achieves the goal of Suryodaya without distorting load structure or wheeling power long distance. As net sellers of day-time power to the grid, tubewell owners will be part of the load management solution for the Utility. 
The proposal discussed will create a metering regime in which farmers work with the Utility as partners rather than adversaries. All these years, farmers have loathed meters as DISCOMs' technology of control. SKY has turned electricity meters into cash meters farmers will guard avidly. SKY farmers keenly track solar generation, consumption and export through SKY mobile application and chase Utility staff to fiX damaged meters. Possibilities also arise of feeder-level farmer organizations aiming to enhance earnings from energy sales by controlling line losses and conserving energy and water.

PMKUSUM-COII will also augur well for carbon footprint of irrigation, eliminating annual use of estimated 17.3 billion kWh (CAG 2016) of mostly thermal energy in pumping groundwater, saving 14.1 million MT of CO2 emissions/year (CEA 2018). Moreover, tubewell solarisation with power-buyback is expected, ceteris paribus, to reduce electricity consumption in pumping groundwater by over 40 percent, reducing significantly, though not proportionately, consumptive use of groundwater in irrigation.

PMKUSUM-COII is a bigger, more profitable approach to ramping up distributed solar generation compared to residential or institutional rooftop solar capacity GoG is aggressively promoting. Rooftop solar robs DISCOMs of their premium customers while 'farm-top' solar (for tubewells) liberates them from subsidy burden.

[1] Professor Emeritus, Institute of Rural Management, Anand

[2] Independent researcher

[3] Throughout this paper, US \$= 72 Indian Rupees

[4] Roughly translated, "Solar Energy for Farmers Scheme".

[5] Public sector National Bank for Agriculture and Rural Development

[6] Including the NABARD loan repaid through EBI by government

[7] Tariff in Indian Rupees in 1988 converted to US \$ at Rs 72/\$.

[8] Lighted Village scheme

[9] Gujarat Energy Regulatory Commission

[10] https://www.inflationtool.com/indian-rupee

[11] Gujarat Urja Vikas Nigam Ltd, a modern avatar of erstwhile Gujarat Electricity Board and the holding company of DISCOMs.

[12] Assuming unmetered connections are chargeable at US $\$ 11.21 / \mathrm{HP} /$ year which was subsequently reduced to US \$9.24/HP/year.

[13] Such as Pani Bachao, Paisa Kamao (Save Water, Earn Cash) in Punjab. See https://www.pspcl.in/2019/08/pspcl-launches-second-phase-of-paani-bachao-paisa-kamao-scheme/ 
[14] Roughly translated as South Gujarat Electricity Company Ltd. Likewise, MGVCL is Central, PGVCL is Western and UGVCL is Northern Gujarat Electricity Company.

[15] The higher load of SKY tubewells is partly explained by special permission given to increase load as a reward to adopters.

[16] Assuming capital cost in 2018 of US $\$ 625 / \mathrm{kWp}$ and $1.25 \mathrm{kWp}$ of panels per HP, farmer contribution is US $\$ 39.1 / \mathrm{HP}$.

[17] (PV of annual gross benefit for 25 years discounted at 10 percent/Year)/( initial capital investment+PV of future costs). PV computed using https://www.calculatorsoup.com/calculators/financial/net-present-value-calculator.php [18] https://www.gercin.org/wp-content/uploads/2020/03/Tariff-Press-Note-March-2020.pdf [19] 65 percent of US $\$ 625 / \mathrm{kWp} * 1.25 \mathrm{kWp} / \mathrm{HP}$ [20] Prime Minister's Initiative for Farm Energy Security and Upliftment [21] http://www.ugvcl.com/solarrooftop/Component\%20C-GOG\%20GR\%20851-B1-06.11.2020.pdf [22] That is $1.31 \mathrm{kWp} / \mathrm{HP}$. MNRE guidelines allow a panel-to-load multiple of 2 (i.e. $1.5 \mathrm{kWp} / \mathrm{HP}$ ). See https://mnre.gov.in/img/documents/uploads/file_s-1607072960786.pdf

[23] $1 \mathrm{HP}$ entitles a farmer to $1.31 \mathrm{kWp}$ of panels costing US $\$ 728$ by contributing US\$291/HP while GoG \& MNRE bear the balance of US \$437/Hp. At $1500 \mathrm{kWh} /$ year, these generate $1965 \mathrm{kWh} /$ year which if sold to the grid fetch US \$77.2/year @ US \$39.3/MWh with a PV, over 25 years, of US \$ 701, NPV of US $\$ 410 / \mathrm{HP}$ and $\mathrm{BC}$ ratio of 2.41 .

[24] Assuming CAG's average of $1835 \mathrm{kWh} / \mathrm{HP}$ and its average value in irrigation and water sale at US \$ $55.55 / \mathrm{mWh}$ over 25 years discounted at 10 percent/year

[25] We assume it will be lower now than in 2018 when SKY began due to fall in PV cell prices and larger volumes involved.

[26] http://164.100.24.220/loksabhaquestions/annex/175/AU1628.pdf

[27] This involves 18 million kWp of solar capacity (1.75 times 10.3 million $\mathrm{kW}$ or 13.7 million HP) at US $\$$ $555.6 / \mathrm{kWp}$.

\section{References}

CAG. Report of the Comptroller and Auditor General of India on Public Sector Undertakings for the year ending March 31, 2015. Gandhinagar: Government of Gujarat, Report 1 (2016).

Central Electricity Authority (CEA). CO2 Baseline Database for the Indian Power Sector, New Delhi: Government of India, https://cea.nic.in/wp-content/uploads/baseline/2020/07/user_guide_ver14.pdf (2018)

Dubash, N.K. The Electricity-Groundwater Conundrum: Case for a Political Solution to a Political Problem. Economic and Political Weekly, 42(52), 45-55 (2007).

Fishman, R, U Lall, V Modi and N Parekh. Can Electricity Pricing Save India's Groundwater? Field Evidence from a Novel Policy Mechanism in Gujarat. Journal of the Association of Environmental and Resource 
Economists 3(4), 819-855 (2016).

Gulati M and S Pahwa. Direct Delivery of Power Subsidy to Farmers in India, Washington: SE4All \& The World Bank, https://esmap.org/sites/esmap.org/files/DocumentLibrary/ SE4All-

\%20Direct\%20Delivery\%20of\%20Power\%20Subsidy\%20to\%20Agriculture\% 20in\%20India_Optimized.pdf. (2015).

Hardiman, D. Well Irrigation in Gujarat: Systems of Use, Hierarchies of Control. Economic and Political Weekly 33(25), 1533-44 (1998).

Jayan, T.K. Solar Pumps: A Non-descript village in Gujarat shows the way", New Delhi: The Hindu BusinessLine, February 8, https://www.thehindubusinessline.com/news/solar-pumps-a-nondescriptvillage-in-gujarat-shows-the-way/article22694612.ece (2018).

Joshi, V., and Acharya, A. Addressing Agricultural Power Subsidy: A Case Study of North Gujarat. Working Paper 2. Surat, India: Center for Social Studies (2005).

Kahneman, D., and Tversky, A. Prospect theory: An analysis of decision under risk. Econometrica, 47, 263291 (1979).

KERC. Karnataka Electricity Regulatory Commission Tariff Order 2017. Karnataka Electricity Regulatory Commission. http://164.100.133.69/kerc/Court\%20Orders/Tariff\%202017/BESCOM/9.\%20BESCOM\%20\%20DIRECTIVES.pdf. (2017).

Kishore, A, Verma, S. and Scott, C.A.Power Supply to Agriculture: Reassessing the Options", Anand: IWMITata Water Policy Highlight \# 7, http://www.iwmi.cgiar.org/iwmitata_html/PM2003/PDF/07_Highlight.pdf. (2004).

Kumar, M, D., Bassi, N. and Verma, M.S. Direct delivery of electricity subsidy to farmers in Punjab: will it help conserve groundwater?, International Journal of Water Resources Development, DOI:

10.1080/07900627.2021.1899900 (2021).

Lacy, S. This is what utility death spiral looks like: In Germany, utility revenues are driving down the rabbit hole; will Americal power companies follow?" GTM, March

4. https://www.greentechmedia.com/articles/read/this-is-what-the-utility-death-spiral-looks-like (2014).

Mishra. S. Alternative Institutions for Electricity Retailing: Assessment of Orissa Experiment", Anand: IWMI-Tata Program Working Paper (2004).

Molle, F and A Closas. Groundwater metering: revisiting a ubiquitous 'best practice', Hydrogeology Journal https://doi.org/10.1007/s10040-021-02353-9. (2021).

MoWR, Gol. National Water Policy 2002, New Delhi: Government of India, Ministry of Water Resources, April, http://jalshakti-dowr.gov.in/sites/default/files/nwp20025617515534_1.pdf (2002) 
Prayas (Energy Group). Understanding the electricity, water, agriculture linkages: Volume II”, Pune India: Prayas Energy Group, September (2018).

Shah, T. Taming the Anarchy: Groundwater Governance in South Asia. Washington D.C.: RFF press (2009).

Shah, T. Groundwater Grids in the Villages of Gujarat: Evolution, Structure, Working and Impacts. Wamana 14-29 (1989).

Shah, T. Groundwater Markets and Irrigation Development: Political Economy and Practical Policy, Bombay: Oxford University Press (1993).

Shah, T. and Chowdhury, S. D. Farm Power Policies and Groundwater Markets: Contrasting Gujarat with West Bengal (1990-2015). Economic and Political Weekly, 52(25-26), 39-47 (2017).

Shah, T., Durga, N., Rai, G.P., Verma, S. and Rathod, R. Promoting Solar Power as a Remunerative Crop. Economic \& Political Weekly, 52(45), 14-19 (2017).

Shah, T., Rajan, A., Rai, G.P., Verma, S. and Durga, N. Solar Pumps and South Asia's Energy-Groundwater Nexus: Exploring Implications and Reimagining Its Future. Environmental Research Letters Journal 13 (2018) 115003 https://doi.org/10.1088/1748-9326/aae53f (2018).

Shah, T., Scott, C.; Kishore, A. and Sharma, A. Energy-Irrigation Nexus in South Asia: Improving Groundwater Conservation and Power Sector Viability. Colombo, Sri Lanka: International Water Management Institute Research Report \# 70 (2004)

Shirisath, P., Saini, S., Durga, N., Senonor, D., Ghose, N., Verma, S. and Sikka, A. Compendium on Solar Powered Irrigation Systems in India", CCAFS, CGIAR, September (2020).

https://ccafs.cgiar.org/resources/publications/compendium-solar-powered-irrigation-systems-india

Sythoff, F.T. Can Energy as a service save power utilities from a death spiral?" Greenbird, Augts 02, https://www.greenbird.com/news/utility-death-spiral. (2019).

The World Bank. Grow Solar, Save Water, Double the Income: An innovative approach to addressing Water-Energy-Agriculture Nexus in Rajasthan" November 11th, draft paper. (2019).

Times of India (Tol). Farm income, MSP, row over new laws: All explained in 5 charts. December 18, 2020. https://timesofindia.indiatimes.com/india/farm-income-msp-row-over-new-laws-all-explained-in-5charts/articleshow/79798223.cms (2020).

United States Agency for International Development (USAID) Evaluation of DRUM and WENEXA. The United States Agency for International Development (USAID). Retrieved from: http://pdf.usaid.gov/pdf_ docs/PDACR528.pdf. (2011). 
Vala. R.J. SKY Business Model for Solarisation of Agriculture Pumpsets, presentation made in World Bank Seminar on, “Grow Solar, Save Water, Double Farm Income' in New Delhi (2020).

Viswanathan, P.K. Trends and Determinants of Agricultural Power Consumption and Distribution Losses: An analysis of agricultural feeders across power distribution companies in Gujarat", Gandhinagar, Gujarat Institute of Developent Research, report for GERC (2014).

\section{Figures}

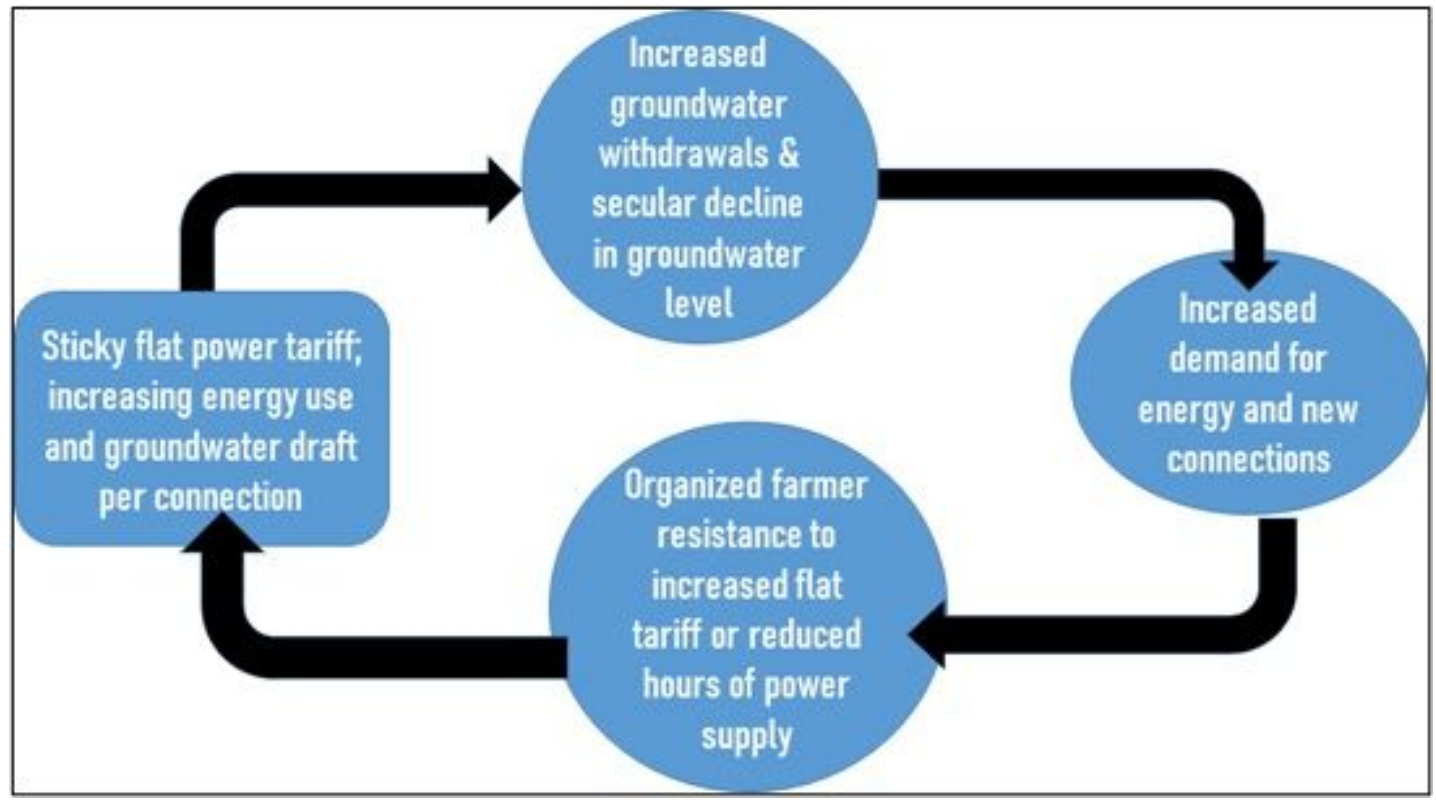

\section{Figure 1}

Nexus between electricity subsidies and groundwater Depletion in Gujarat

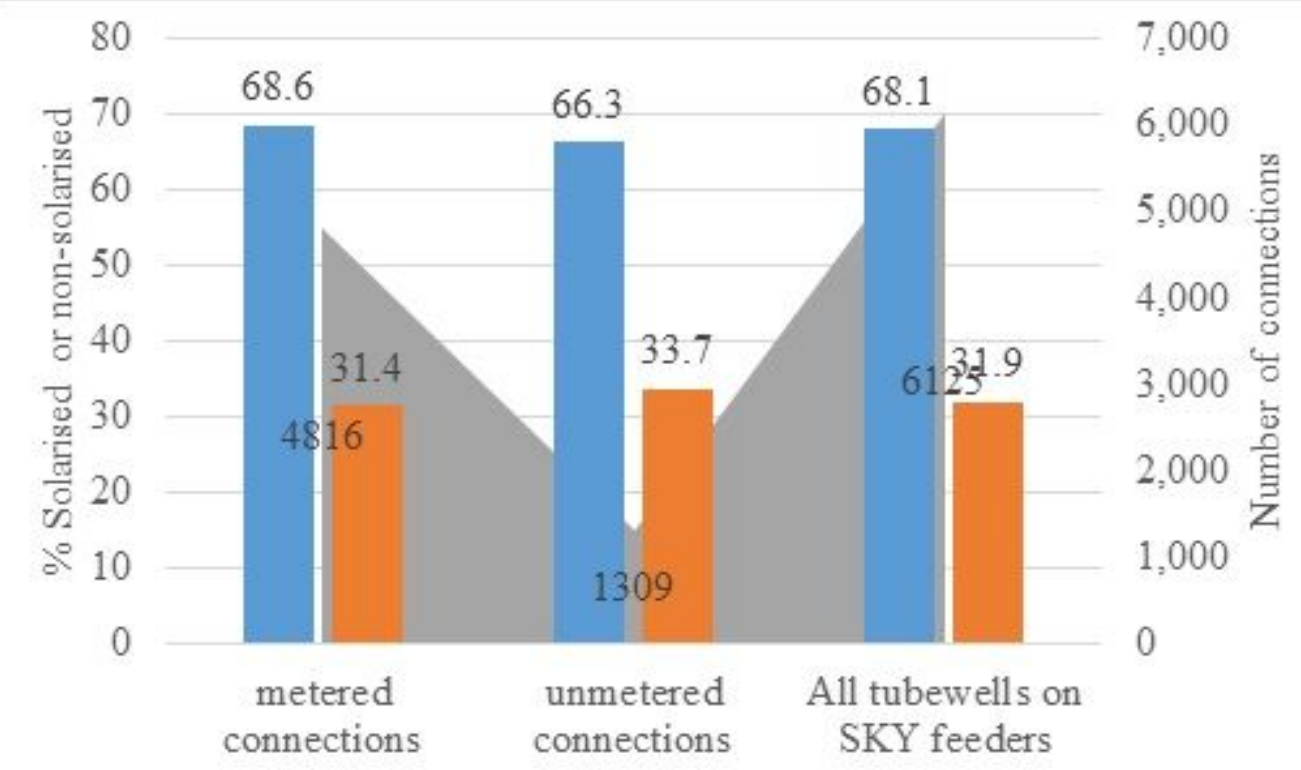

- No.of tubewells on SKY feeders $\quad \%$ solarised $=\%$ mon-solarised 
Figure 2

Response of owners of metered and unmetered tubewells to Solarization and Net-metering under Gujarat's SKY Scheme

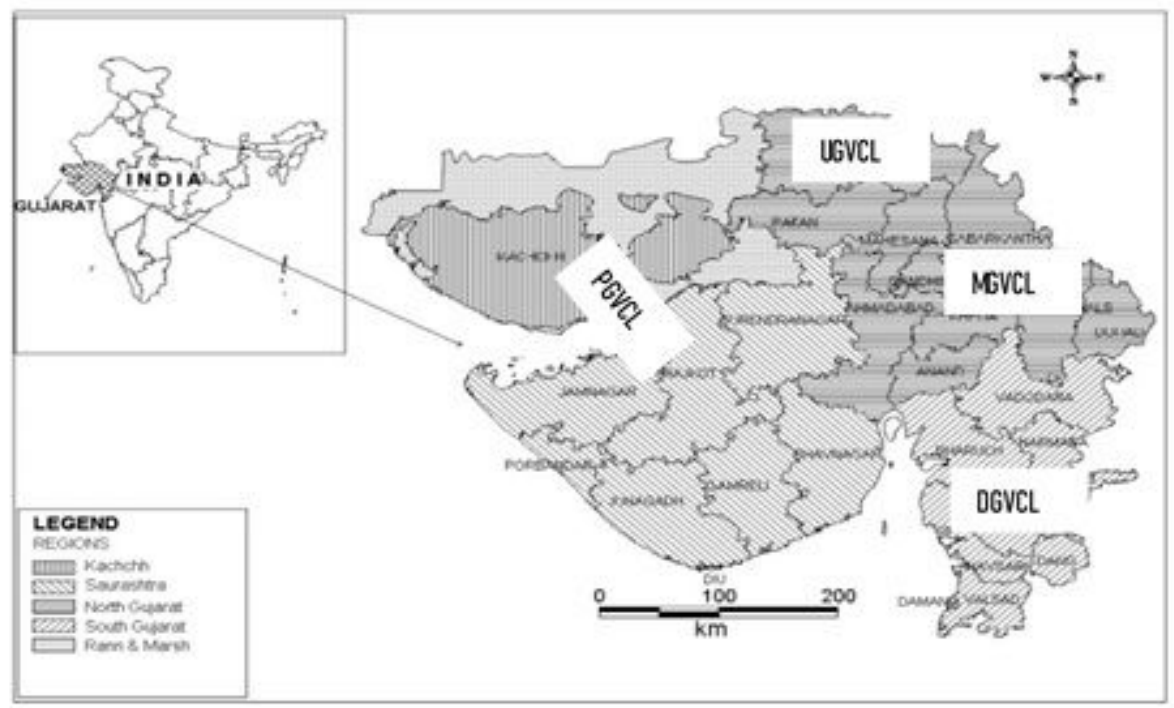

Figure 3

Physiography of Service Areas of Gujarat DISCOMs

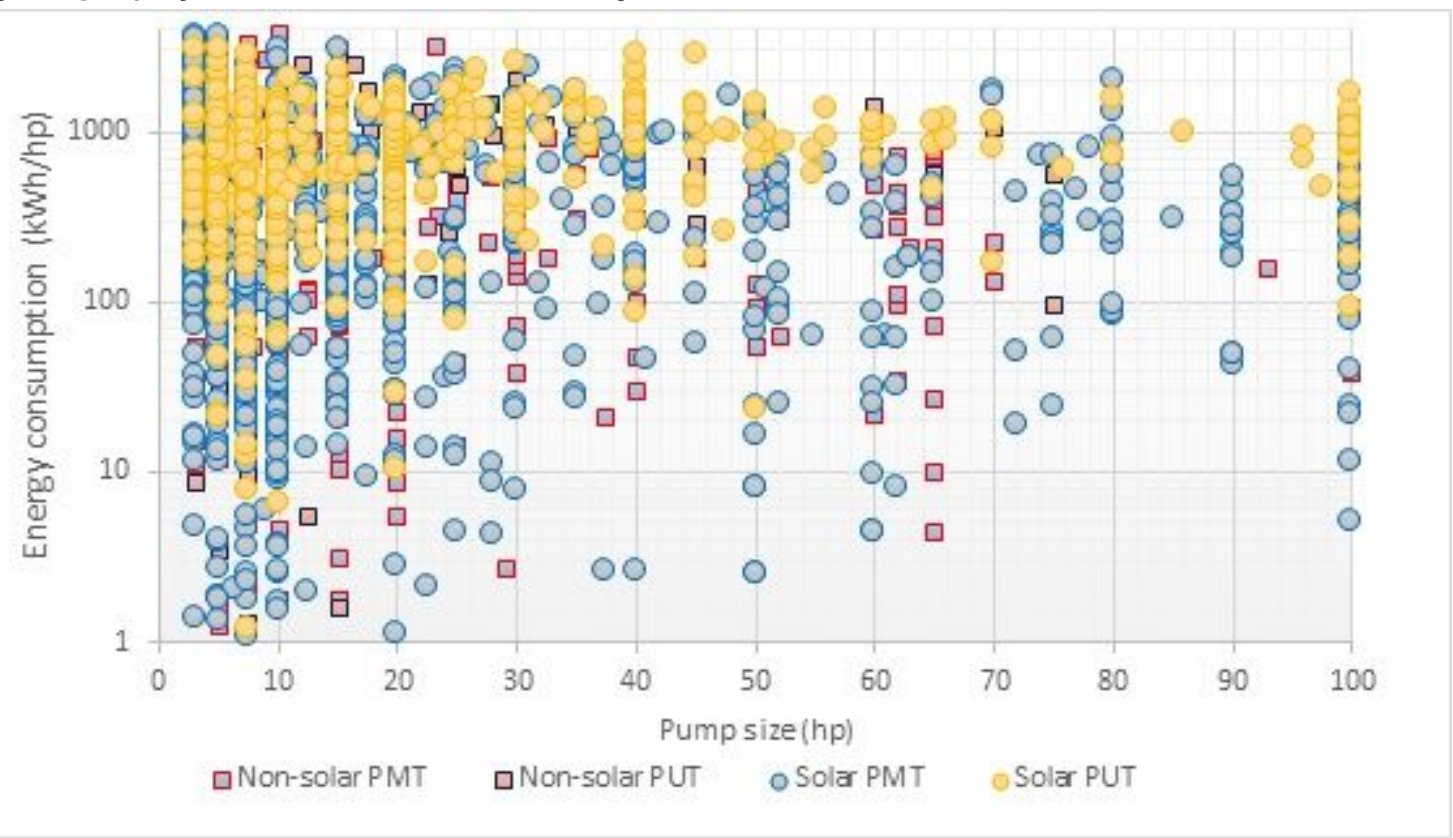

Figure 4

Log of energy consumption/HP against tubewell capacity (HP) 


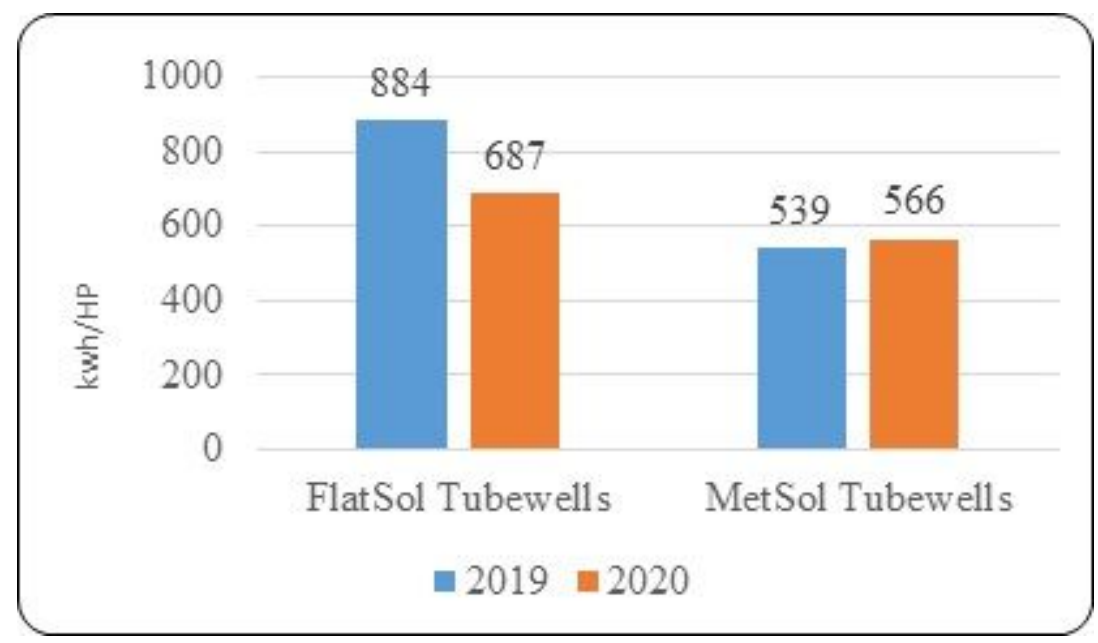

Figure 5

Change in power consumption/HP over 2019 and 2020 in 12 SKY feeders across 4 DISCOMs

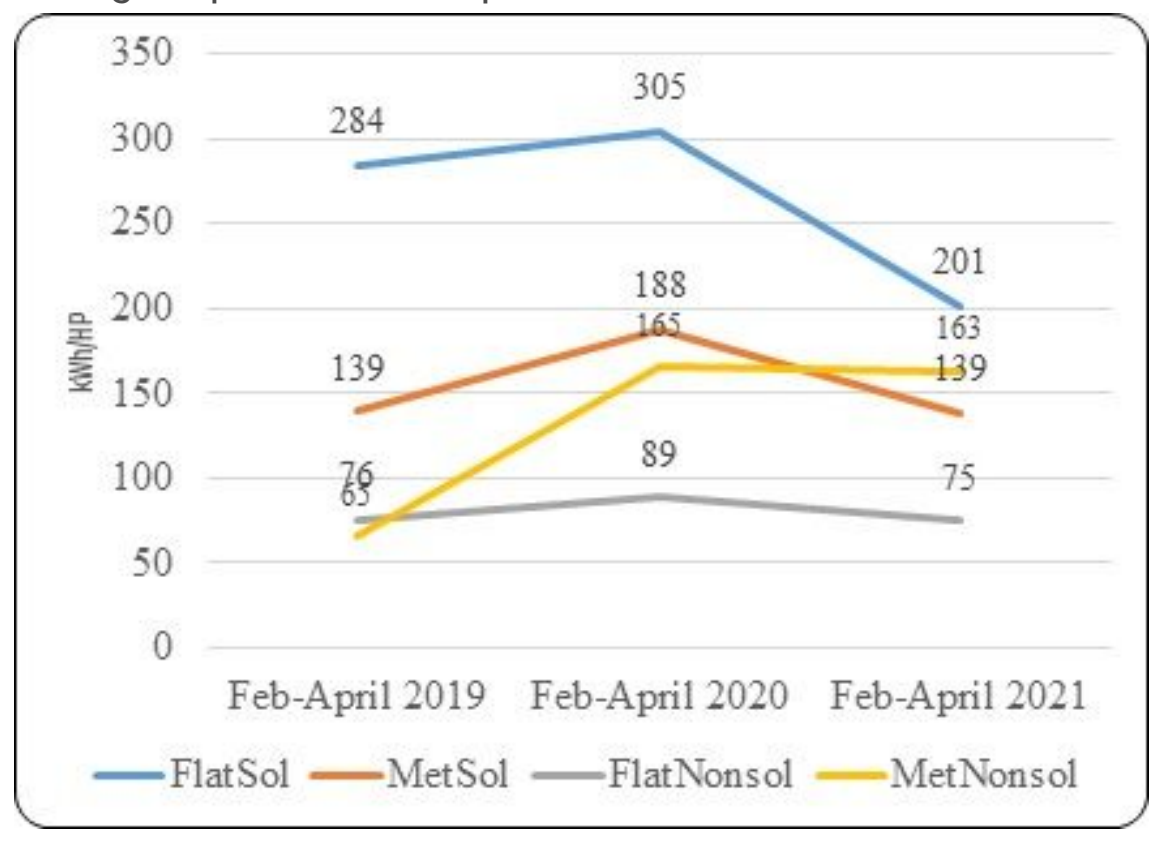

Figure 6

Trend in power consumption/HP during peak irrigation months 


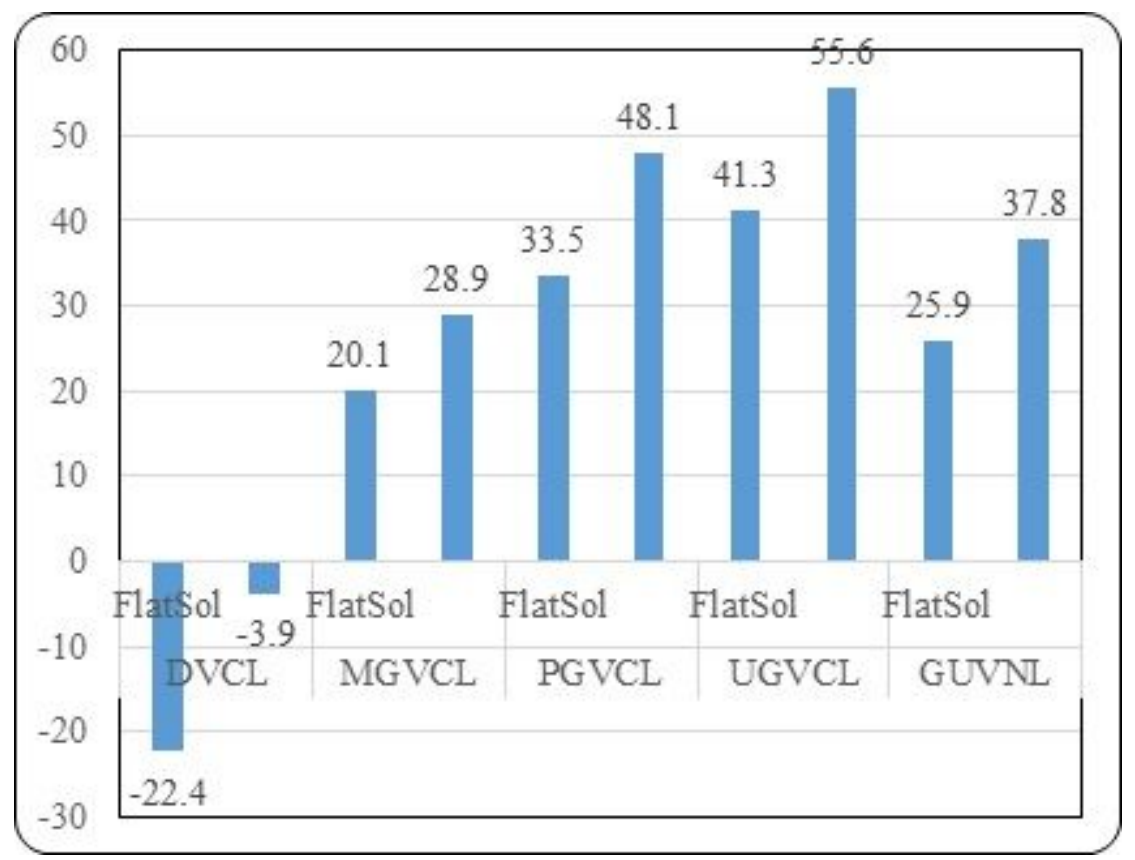

Figure 7

SKY Farmers: Average gain from energy sale/HP (US \$)

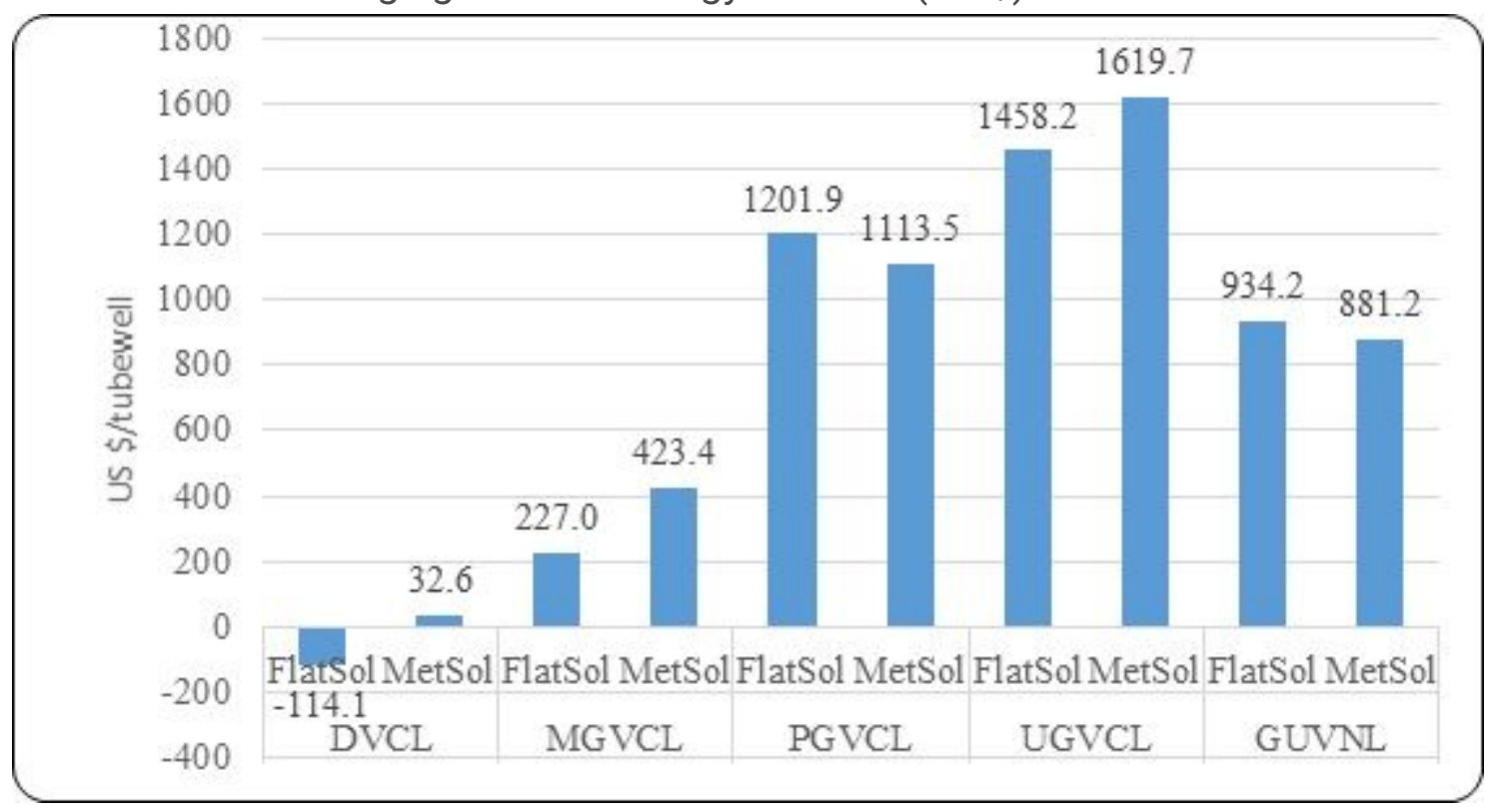

Figure 8

SKY farmers' average gain/tubewell (from energy sales plus tariff saved less loan instalment) (US \$) 


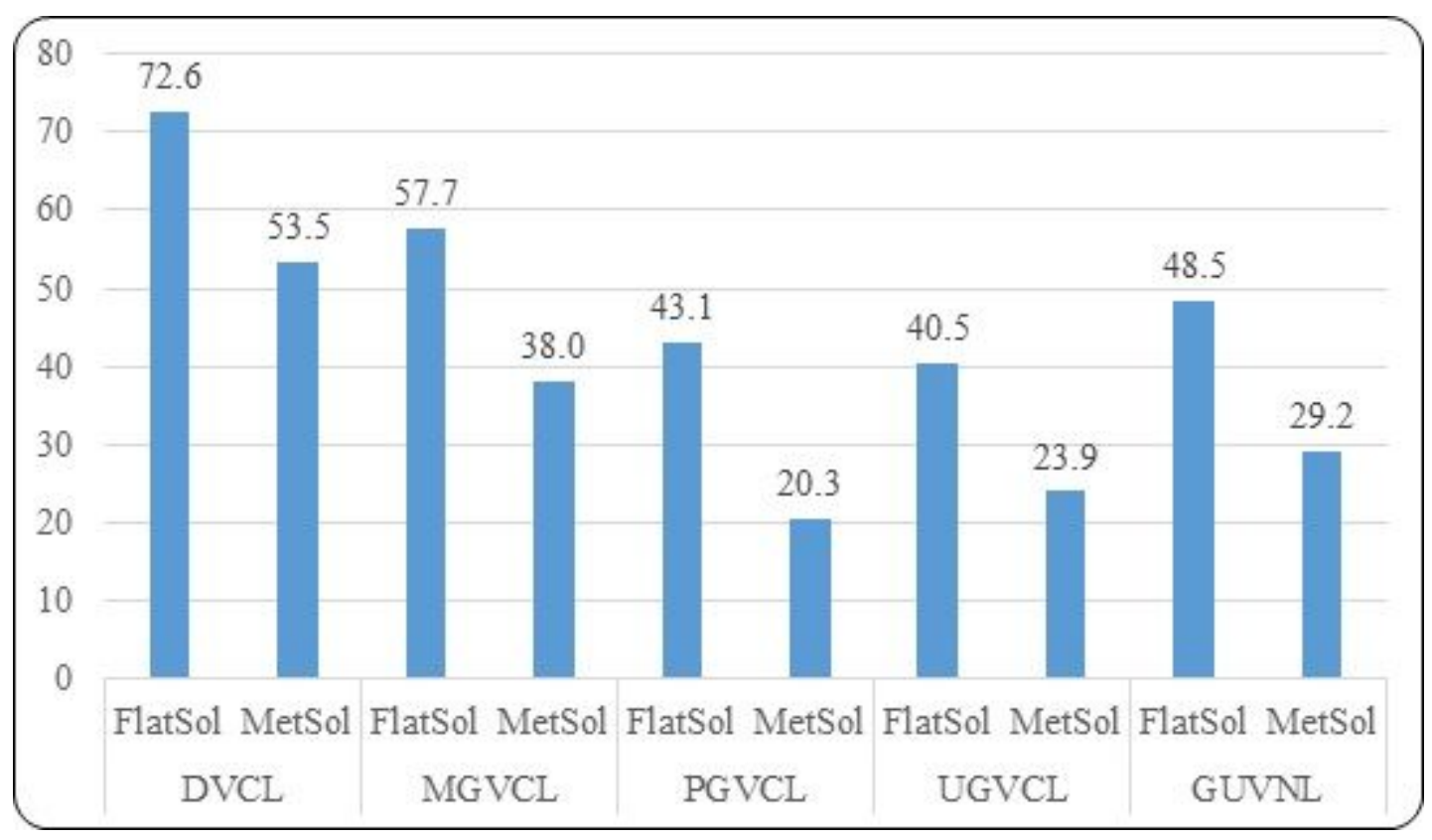

Figure 9

SKY Farmers: energy consumed as \% of solar generation

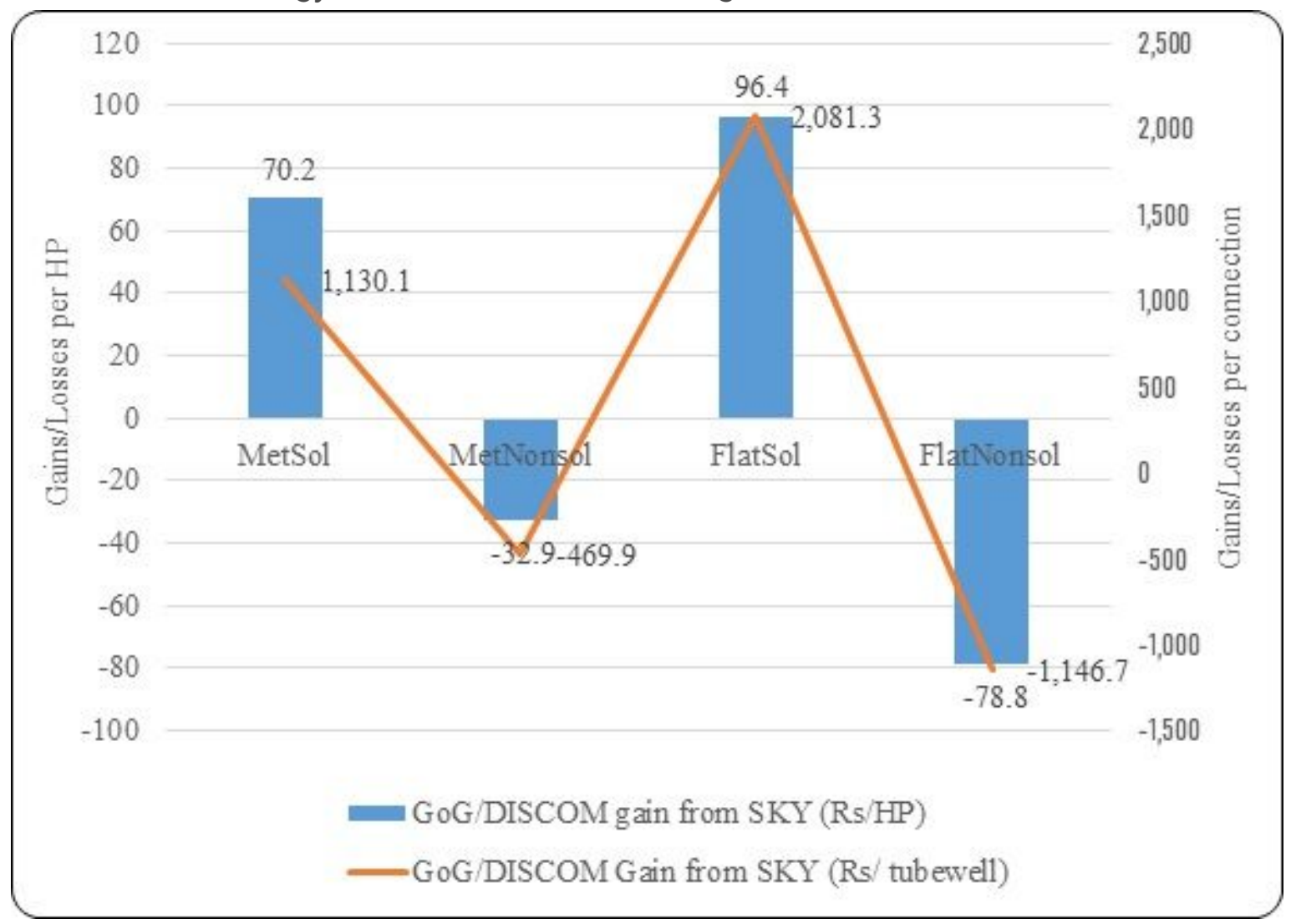

Figure 10

GoG-DISCOM Gains from Solarised Tubewells and Losses from non-solarised Tubewells on SKY feeders 5934 tubewells and 97107 HP load 


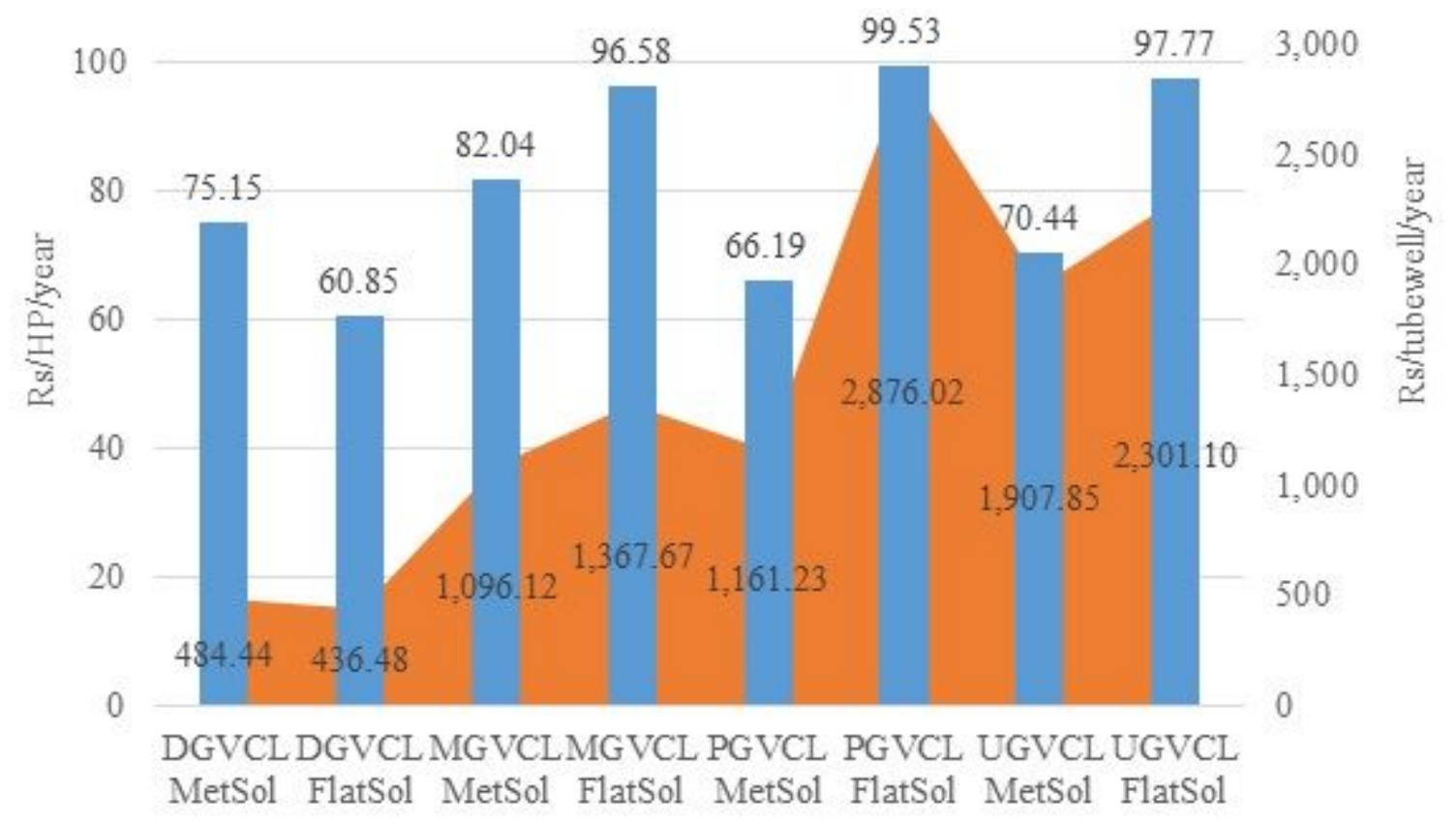

$=\mathrm{GoG} / \mathrm{DISCOM}$ Gain from SKY (Rs/tubewell) $=\mathrm{GoG} / \mathrm{DISCOM}$ gain from SKY (Rs/HP)

\section{Figure 11}

Gains/HP and Connection from SKY: DISCOM and GoG Perspective

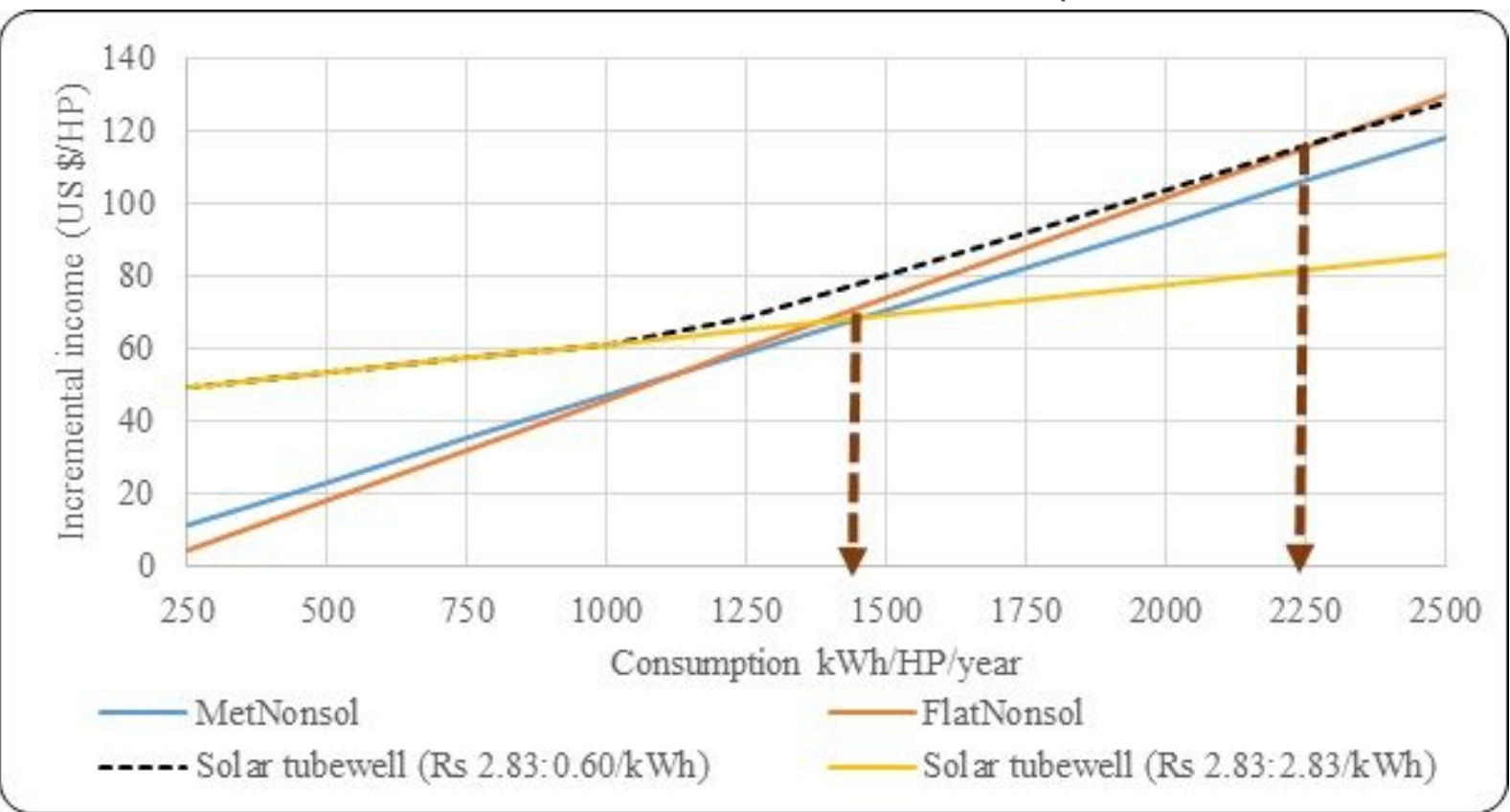

Figure 12

Breakeven level of consumption/HP beyond which adopter loses from PMKUSUM COII 


\section{Supplementary Files}

This is a list of supplementary files associated with this preprint. Click to download.

- Annexure1SKYassessment.docx 